Original Research Paper

\title{
Sistem Informasi Pengelolaan Pengunjung Pada Saat Pandemik Covid-19
}

\author{
Fauzan $^{1}$, Abdul Rohmad Basar' ${ }^{1}$, Maria Olva ${ }^{2}$, Pratiwi Hendro Wahyudiono ${ }^{3}$, Nur Iksan ${ }^{4}$, \\ Achmad Yani ${ }^{5}$
}

${ }^{1}$ Fakultas Teknik, Universitas Ibnu Sina. Batam, Indonesia.

${ }^{2}$ PT. Prima Labeling. Batam, Indonesia.

${ }^{3}$ Program Magister Teknik, Fakultas Teknik, Universitas Andalas. Padang, Indonesia.

${ }^{4}$ Fakultas Teknik, Universitas Riau Kepulauan (UNRIKA). Batam, Indonesia.

${ }^{5}$ Teknik Perkapalan, Fakultas Teknik, Universitas Hasanuddin. Makassar, Indonesia.

Article History
Received:
12.07.2021
Revised:
27.07 .2021
Accepted:
04.08 .2021
*Corresponding Author:
Fauzan
Email:
akhi.fauzan@gmail.com

This is an open access article, licensed under: $\mathrm{CC}-\mathrm{BY}-\mathrm{SA}$
Abstrak: PT. Epson Batam (PEB) adalah perusahaan multinasional dengan jumlah karyawan lebih dari 3000 orang. Banyaknya tamu (non-karyawan) yang datang ke PT. Epson Batam setiap harinya seperti kunjungan dari instansi pemerintah, partner perusahaan, vendor dan supplier, menyebabkan adanya kebutuhan terhadap aplikasi khusus yang dapat memudahkan perusahaan dalam mengelola data-data para tamu yang berkunjung ke perusahaan dan memudahkan pihak pengaman perusahaan dalam melakukan pencatatan dan rekap tamu yang berkunjung. Penelitian ini bertujuan untuk merancang sebuah sistem informasi pengelolaan pengunjung di masa pandemik Covid-19. Berdasarkan maklum balas dari pengguna disimpulkan bahwa sistem yang dibangunkan bisa digunakan dan berfungsi dengan baik tetapi perlu pengembangan yang memungkinkan sistem informasi terintegrasi dengan alat pengukur suhu.

Kata Kunci: Covid-19, Sistem Informasi, Pengelolaan Pengunjung.

Visitor Management Information System during the Covid-19 Pandemic

Abstract: PT. Epson Batam (PEB) is a multinational company with more than 3000 employees. The number of guests (non-employees) who come to PT. Epson Batam every day such as visits from government agencies, company partners, vendors and suppliers, causes the need for special applications that can make it easier for companies to manage the data of guests who visit the company and make it easier for company security to record and recap guests who visit the company. This study aims to design a visitor management information system during the Covid-19 pandemic. Based on the feedback from users, it is concluded that the system developed can be used and functions well but needs development that allows an integrated information system with temperature measuring devices.

Keywords: Covid-19, Information System, Management Visitor. 


\section{Pendahuluan}

Proses penerimaan tamu menjadi bagian penting bagi suatu instansi karena merupakan penghubung dan penyaji informasi. Hal ini dikarenakan penerima tamu merupakan tempat pertama dan terakhir yang dijumpai oleh tamu, sehingga kesan pertama dan kesan terakhir terbentuk di penerima tamu ini [1]

PT. Epson Batam adalah perusahaan multinasional dengan jumlah karyawan lebih dari 3000 orang. Berperan sebagai bagian dari Seiko Epson Corporation (SEC) dengan hasil produksi diantaranya berupa device, scanner dan tinta. Perusahaan ini didirikan pada Juni 1991 dan mulai beroperasi pada Juli 1991 berlokasi di Lot 504-508A Batamindo Industrial Park Mukakuning, Batam, Indonesia [2].

Banyaknya tamu (bukan karyawan) yang datang ke PT. Epson Batam setiap harinya seperti kunjungan dari instansi pemerintah, partner perusahaan, vendor dan supplier, menyebabkan adanya kebutuhan terhadap aplikasi khusus yang dapat memudahkan perusahaan dalam mengelola data-data para tamu yang berkunjung ke perusahaan dan memudahkan pihak security perusahaan dalam melakukan pencatatan dan rekap tamu yang berkunjung.

Dari hasil observasi dan wawancara yang dilakukan dengan manajer Ibu Information System Department (ISD) di PT. Epson Batam, penulis mendapati bahwa perlu dilakukan perbaikan pada sistem pengelolaan tamu/pengunjung bukan karyawan di PT. Epson Batam. Yang dikategorikan pengunjung PT. Epson Batam adalah semua orang yang datang ke PT. Epson Batam dan tidak terdaftar sebagai karyawan di PT. Epson Batam. Dan pengunjung ini ada yang kategorinya pengunjung rutin dan ada pengunjung tidak rutin. Yang termasuk kategori pengunjung rutin adalah karyawan koperasi, petugas kesehatan seperti dokter dan apoteker yang bekerja di klinik PT. Epson Batam, vendor-vendor material barang, jasa catering atau pemasok yang hanya datang untuk mengantarkan barang. Sedangkan pengunjung tidak rutin yaitu tamu bukan karyawan yang memiliki keperluan khusus dengan pihak karyawan PT. Epson Batam dan umumnya sudah ada perjanjian ketemu dengan karyawan PT. Epson Batam.

Aplikasi yang digunakan di PT. Epson Batam saat ini adalah PEB Security Gate baik untuk pengunjung yang rutin maupun pengunjung tidak rutin. Adapun untuk karyawan cukup melakukan proses tapping di pintu pedestrian. Sedangkan untuk pengunjung (bukan karyawan) maka harus menjumpai pihak penjaga untuk register lalu dicatat identitas diri, kemudian diberikan pengunjung card. Aplikasi Security Gate ini berfungsi untuk mencatat indentitas dari pengunjung seperti nomor Kartu Tanda Penduduk (KTP), nama lengkap, perusahaan, nomor telepon, nomor plat kendaraan, tujuan berkunjung, dan siapa karyawan PT. Epson Batam yang ingin ditemui.

Setelah dicatat oleh penjaga, kemudian pengunjung diizinkan masuk. Adapun untuk pengunjung yang memiliki janji temu atau keperluan khusus dengan karyawan PT. Epson Batam akan menuju ke lobi perusahaan. Di lobi perusahaan, tamu akan disambut oleh resepsionis lalu kemudian menanyakan siapa pihak karyawan yang ingin ditemui. Setelah itu, resepsionis akan menghubungi pihak karyawan PT. Epson Batam dan menginformasikan bahwa tamu sudah menunggu di lobi.

Dari hasil wawancara yang penulis lakukan juga didapati bawah kendala yang terjadi adalah PT. Epson Batam masih menggunakan bantuan resepsionis untuk menyambut tamu. Proses manual ini mengharuskan resepsionis untuk selalu berada di meja penerima tamu karena setelah tamu datang sampai di lobi, resepsionis ini yang akan menerima tamu. Jadi masih ada interaksi antara resepsionis dan pengunjung. Tamu akan melapor kepada resepsionis di lobi, lalu kemudian resepsionis akan menghubungi karyawan perusahaan yang akan ditemui melalui telepon dan memberitahukan bahwa tamu sudah menunggu di lobi.

Adapun perbaikan yang diharapkan antara lain seperti proses register pengunjung yang terkoneksi dengan kamera untuk mengambil foto pengunjung, sehingga data identitas pengunjung lebih lengkap, kemudian menyediakan fasilitas pertemuan (agreement for meeting) atau janji temu yang memudahkan karyawan untuk mendaftarkan tamu yang akan datang.

Disamping itu, sistem ini menyediakan peralatan yang dapat memudahkan proses pencarian pengunjung dan pencarian data-data tamu yang sudah pernah berkunjung ke PT. Epson Batam lengkap dengan informasi identitas pribadi tamu, tujuan kunjungan, pihak karyawan yang ditemui berserta foto tamu tersebut. Dan juga ada alat yang dapat melakukan pemberitahuan secara otomatis kepada pihak karyawan yang dikunjungi ketika tamu sudah sampai di lobi perusahaan. Karena proses yang berjalan saat ini mengharuskan resepsionis selalu bersiaga karena saat tamu tiba di lobi perusahaan, mereka akan melapor kepada resepsionis di lobi, lalu kemudian resepsionis akan menghubungi karyawan perusahaan yang akan ditemui melalui telepon dan memberitahukan bahwa tamu sudah menunggu di lobi. 
Oleh karena itu, penelitian ini ditujukan untuk merancang dan mengimplementasikan Sistem Manajemen Pengunjung yang memiliki beberapa proses seperti pencatatan tamu pada pos jaga serta menyediakan menu appointment untuk kunjungan atau janji temu yang nantinya semua itu terkoneksi dengan aplikasi e-lobby yang menggantikan peran resepsionis termasuk notifikasi otomatis melalui Short Message Service (SMS) saat tamu sudah tiba di ruangan lobi perusahaan, juga menyediakan menu untuk tracing pengunjung jika sekiranya ada keperluan untuk melacak siapa saja tamu yang berkunjung ke PT. Epson pada waktu tertentu.

\section{Landasan Teori}

Dalam perancangan Sistem Informasi Pengelolaan Pengunjung, terdapat teori-teori ilmu yang digunakan untuk membantu penelitian yang berkaitan dengan sistem yang akan dibuat. Tujuannya adalah agar rancangan ini memiliki pijakan pustaka yang dapat dipertanggungjawabkan.

\subsection{Pengunjung}

Pengunjang/tamu ialah tamu organisasi, badan, lembaga, atau perusahaan, yaitu orang, baik sebagai pejabat utusan dari suatu forum maupun sebagai pribadi, yang berkunjung ke forum lain untuk kepentingan kedinasan maupun untuk kepentingan pribadi. [3] Tamu juga dapat didefinisikan sebagai organisasi atau perusahaan maupun seseorang atau sekelompok orang yang membawa satu atau beberapa kepentingan, baik itu kepentingan dirinya sebagai pribadi, maupun kepentingan orang lain, termasuk kepentingan organisasi tertentu dimana mereka merupakan utusan dari organisasi tersebut. [4]

\subsection{Pengelolaan}

Pengelolaan merupakan istilah yang dipakai dalam ilmu manajemen. Secara etomologi istilah pengelolaan berasal dari kata kelola (to manage) dan biasanya merujuk pada proses mengurus atau menangani sesuatu untukmencapai tujuan tertentu. Jadi pengelolaan merupakan ilmu manajemen yang berhubungan dengan proses mengurus dan menangani sesuatu untuk mewujudkan tujuan tertentu yang ingin dicapai [5].

\subsection{Sistem}

Secara sederhana sistem dapat diartikan sebagai salah satu kumpulan atau himpunan dari unsur, komponen, atau variabel yang terorganisasi, saling berinteraksi, saling tergantung satu sama lain dan terpadu. Sistem adalah suatu susunan yang teratur dari kegiatan-kegiatan yang saling berkaitan dan susunan prosedur-prosedur yang saling berhubungan, sinergi dari semua unsur-unsur dan elemenelemen yang ada didalamnya, yang menunjang pelaksanaan dan mempermudah kegiatan-kegiatan utama dari suatu organisasi ataupun satuan kerja [6].

\subsection{Informasi}

Informasi berguna untuk pembuat keputusan karena informasi menurunkan ketidakpastian atau meningkatkan pengetahuan. Informasi menjadi penting karena berdasarkan informasi itu pengelola dapat mengetahui kondisi objektif perusahaannya. Informasi tersebut merupakan hasil pengolahan data atau fakta yang dikumpulkan dengan metode ataupun cara-cara tertentu [7]. Informasi dan data memiliki keterkaitan erat. Informasi adalah data yang diperoleh menjadi bentuk yang lebih berarti/memiliki makna. Sedangkan data sendiri adalah sekumpulan karakter yang menggambarkan kejadian atau fakta-fakta yang terjadi pada saat tertentu [8].

\subsection{Sistem Informasi}

Keterkaitan antara data dan informasi menjadi entitas penting dalam pembentuk sistem informasi. Sehingga sistem informasi dapat didefinisikan sebagai suatu alat untuk menyajikan informasi dengan cara sedemikian rupa sehingga bermanfaat bagi penerimanya [9]. Tujuannya adalah untuk menyajikan informasi guna pengambilan keputusan pada perencanaan, pemrakarsaan, pengorganisasian, pengendalian kegiatan operasi subsistem suatu perusahaan dan menyajikan sinergi organisasi pada proses [10]. Masukan adalah data atau informasi yang dibutuhkan oleh sebuah sistem untuk selanjutnya diproses sesuai dengan ketentuan proses yang telah ditentukan.

Pada akhirnya sistem akan menghasilkan keluaran yang bila diperlukan lagi maka hasil keluaran tersebut akan kembali menjadi sebuah input, begitu seterusnya, ini yang kita sebut dengan system life cycle atau siklus hidup sistem [7]. 


\subsection{Pencatatan Data Tamu}

Pencatatan data adalah proses memasukkan data ke dalam media sistem pencatatan data. Jika media sistem pencatatan data tersebut berupa buku, pencatatan data dilakukan dengan menulis pada lembarlembar buku. Jika sistem pencatatan data berupa perangkat komputer, pencatatan dilakukan dengan mengetik melalui keyboard, penggunaan pointer mouse, alat scanner (pembaca gambar), atau kamera video. Yang termasuk dalam pencatatan data adalah aktivitas penulisan ke buku atau kertas, pemasukan data ke dalam computer [11]. Proses pencatatan data tamu di PT. Epson Batam dilakukan saat tamu/pengunjung memasuki gerbang utama perusahaan. Di mana setiap tamu yang ingin berkunjung wajib melapor kepada pihak security terlebih dulu dengan menginformasikan data diri untuk direkap. Kemudian, tamu tersebut akan diberikan kartu pengunjung, yang nantinya digunakan sebagai akses ke lobi perusahaan.

\subsection{Penerima Tamu}

Petugas yang bertugas khusus menerima dan melayani tamu disebut dengan resepsionis atau petugas penerima tamu. Tugas seorang resepsionis adalah membantu para tamu yang ingin bertemu dengan pejabat atau pimpinan. Oleh karena kesan pertama yang diperoleh para tamu adalah sikap resepsionis. Dapat disimpulkan bahwa resepsionis merupakan orang yang bertugas sebagai penerima tamu di suatu perusahaan, kantor, atau hotel. Mereka biasanya ditempatkan dibagian depan kantor, ini bertujuan agar tamu yang datang mudah mengetahui cara yang mudah untuk mencari informasi dan juga sebagai gambaran dari suatu perusahaan [12].

\subsection{Perancangan Sistem}

Perancangan sistem adalah penentuan proses dan data yang diperlukan oleh sistem baru. Tujuan dari perancangan sistem adalah untuk memenuhi kebutuhan pemakai sistem serta untuk memberikan gambaran yang jelas dan rancang bangun yang lengkap. Perancangan sistem Informasi adalah merancang atau mendesain suatu sistem yang baik dimana isinya adalah langkah-langkah operasi dalam proses pengolahan data dan proses prosedur-prosedur untuk mendukung operasi sistem. Tujuan dari perancangan sistem adalah untuk memenuhi kebutuhan para pemakai sistem serta memberikan gambaran yang jelas dan rancang bangun yang lengkap kepada pembuat sistem dan ahli-ahli yang terlibat didalam [13].

Perancangan sistem yang diperkenalkan ini dimulai dari proses pendaftaran [14] [15] [16], kemudian dilanjutkan dengan pengelolaan [17] [18] [19] dan diakhiri dengan pemantauan.

\subsection{System Development Life Cycle}

System Development Life Cycle (SDLC) merupakan siklus pengembangan sistem dengan beberapa proses secara bertahap di dalam merancang dan mengembangkan sistem. SDLC memiliki tahapan dalam pengembangan sistem yaitu, perencanaan, analisis, perancangan, implementasi, dan perawatan (maintenance) [25]. SDLC juga dapat didefinisikan sebagai proses logika yang digunakan oleh seorang analis sistem untuk mengembangkan sebuah sistem informasi yang melibatkan requirments, validation, training dan pemilik sistem [13].

\subsection{Bagan alur}

Bagan alur (flowchart) merupakan metode untuk menggambarkan tahap-tahap penyelesaian masalah (prosedur) beserta aliran data dengan simbol-simbol standar yang mudah dipahami. Tujuan utama penggunaan flowchart adalah untuk menyederhanakan rangkaian proses atau prosedur untuk memudahkan pemahaman pengguna terhadap informasi tersebut. Untuk itu, desain sebuah bagan alur harus ringkas, jelas dan logis [26].

\subsection{Unified Modeling Language}

Unified Modeling Language (UML) adalah bahasa pemodelan untuk sistem atau perangkat lunak yang berparadigma berorientasi objek. Pemodelan (modelling) sesungguhnya digunakan untuk penyederhanaan permasalahan-permasalahan yang kompleks sedemikian rupa sehingga lebih mudah dipelajari dan dipahami [5].

\subsection{Activity Diagram}

Activity diagram atau diagram aktivitas yaitu salah satu jenis diagram pada UML yang dapat memodelkan proses-proses apa saja yang terjadi pada sistem [27]. 


\subsection{Data}

Data merupakan fakta-fakta yang menggambarkan suatu kejadian yang sebenarnya pada waktu tertentu. Jadi data didapat dari suatu kejadian yang benar-benar terjadi [28]. Dalam definisi lain data adalah hasil observasi langsung terhadap suatu kejadian, yang merupakan perlambangan yang mewakili objek atau konsep dalam dunia nyata. Hal ini dilengkapi dengan nilai tertentu [29]. Data juga dapat didefinisikan sebagai fakta atau apa yang dikatakan sebagai hasil dari suatu observasi terhadap fenomena alam. Sebagai hasil observasi langsung terhadap kejadian atau fakta dari fenomena di alam nyata, data bisa berupa tulisan atau gambar yang dilengkapi dengan nilai tertentu [30].

\section{Metode Penelitian}

Metode merupakan bagian dari metodologi. Metodologi itu sendiri berasal dari kata metodos dan logos yang berarti ilmu dari metode. Bila kita melakukan penelitian dimana kita menguraikan caracara dan langkah dalam meneliti, maka itu disebut juga metodologi. Dalam tahapan-tahapan tersebut ada metode, teknik, dan alat (tools) yang bisa kita gunakan [31].

Dalam mengumpulkan data penelitian, penulis melakukan tiga metode penggumpulan data yaitu:

1. Observasi, dengan cara mengamati dan mempelajari tentang flow dan proses penerimaan tamu di PT. Epson Batam.

2. Wawancara, untuk mendapat informasi secara lengkap maka penulis melakukan metode tanya jawab langsung kepada ISD Manager perusahaan yang mengelola dan bertanggung jawab terhadap keseluruhan system yang ada di PT. Epson Batam.

3. Studi pustaka, mengumpulkan teori-teori yang bersumber dari buku-buku serta jurnal-jurnal yang dapat mendukung penelitian ini.

Selain menggunakan metode pengumpulan data, penulis juga melakukan pengembangan sistem dengan metode System Development Life Cycle (SDLC) dan menggunakan model waterfall. Sehingga diharapkan penelitian ini dapat menggambarkan segala peristiwa yang diperoleh di lapangan secara utuh dan dapat digunakan untuk pemecahan masalah yang ada berdasarkan data yang diperoleh. Dalam hal ini dengan cara memberikan penjelasan dan gambaran mengenai flow yang berjalan saat ini terkait manajemen penerimaan tamu di PT. Epson Batam.

\section{Perancangan Sistem}

Analisa perancangan pada penelitian ini terdiri atas:

- analisa perancangan sistem

- analisa perancangan basis data

- analisa perancangan antar muka

\subsection{Analisa Perancangan Sistem}

Pengembangan sistem yang akan dilakukan memerlukan analisis sistem yang tepat sesuai dengan proses bisnis yang ada. Untuk itu berdasarkan observasi yang telah penulis lakukan terkait flow dan proses penerimaan tamu di PT. Epson Batam, maka analisa rancangan sistem dapat dirangkum menjadi beberapa proses.

Proses pencatatan kunjungan tamu dimulai dari karyawan PT. Epson Batam yang membuat janji temu pengunjung untuk tamu yang akan berkunjung. Janji temu pengunjung bisa dibuat jauh-jauh hari sebelum hari kedatangan tamu. Setelah itu, saat tamu datang ke PT. Epson Batam, tamu harus melapor kepada penjaga. Kemudian penjaga akan mengecek pada daftar tamu yang sudah muncul dari data janji temu yang dibuat oleh karyawan PT. Epson Batam. Jika sesuai, penjaga akan memilih dan otomatis akan tampil data dan informasi yang dibutuhkan. Penjaga hanya perlu memasukkan informasi tambahan yang diperlukan seperti suhu tubuh, nomor plat kendaraan dan juga mengambil foto tamu menggunakan kamera yang sudah terhubung dengan sistem.

Setelah itu tamu akan diberikan kartu pengunjung card untuk kemudian dipersilahkan menuju lobi perusahaan. Sesampainya di lobi perusahaan, tamu akan melakukan tapping pada sistem melalui alat pembaca HID, dan otomatis sistem mengirimkan notifikasi kepada karyawan dengan menginformasikan bahwa tamu sudah menunggu di lobi perusahaan. Tamu hanya perlu menunggu di ruang pertemuan.

Karyawan datang ke lobi dan bertemu dengan pengunjung, melakukan pembicaraan dan setelah selesai maka tamu perlu melakukan tapping kembali ke sistem sebagai penanda bahwa tamu sudah selesai dan akan keluar dari kawasan perusahaan. Terakhir tamu tersebut mengembalikan kartu tanda 
pengunjung kepada pihak penjaga perusahaan. Kesemua proses di atas digambarkan melalui skema bagan alir pada Gambar 1.

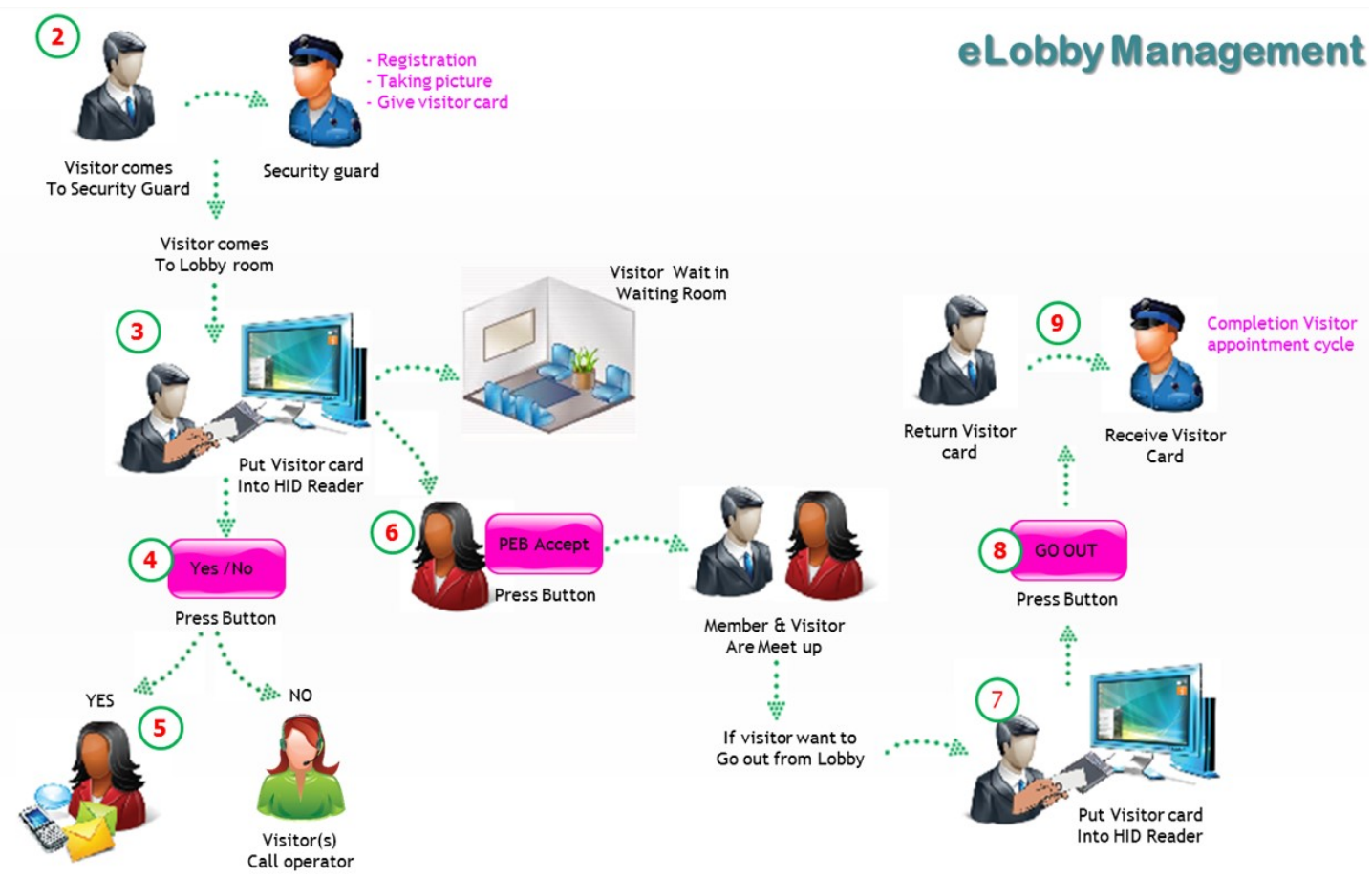

Gambar 1. Bagan Alir Sistem Informasi Pengelolaan Pengunjung

Analisa rancangan use case dari Sistem Informasi Pengelolaan Pengunjung secara keseluruhan terdapat enam proses utama, yaitu proses login, mencatat data tamu, melihat detail informasi tamu, membuat appointment, dan meberikan hak akses. Untuk lebih jelasnya dapat dilihat pada Gambar 2.

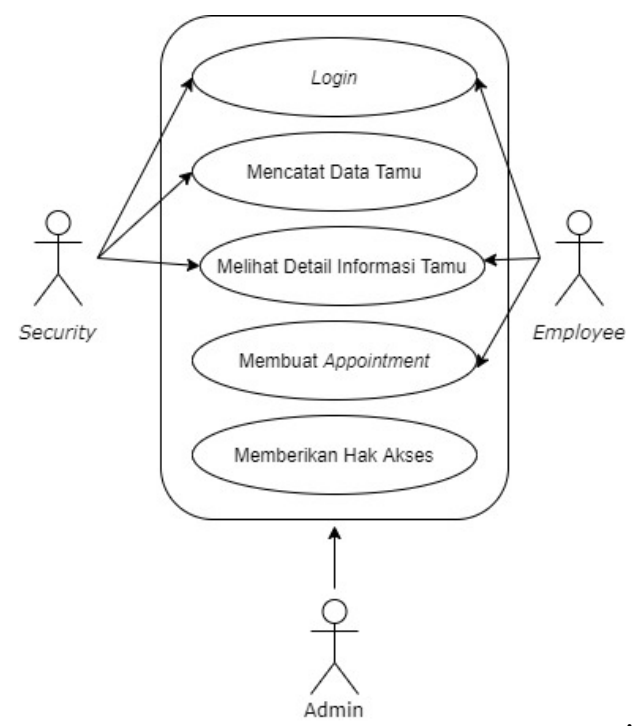

Gambar 2. Sistem Informasi Pengelolaan Pengunjung: Use Case

Pada Gambar 2. dapat dilihat bahwa terdapat tiga aktor (user) sebagai pengguna aplikasi, yaitu 
satpam (security) yang memiliki akses login, mencatat data tamu yang datang dan melihat history detail dari data pengunjung. Kemudian aktor kedua adalah karyawan (employee) memiliki akses login, membuat visitor appointment (janji temu) dengan tamu dan melihat history detail dari data pengunjung. Aktor ketiga adalah admin yang memiliki akses penuh terhadap keseluruhan aplikasi. Beberapa use case tersebut dijelaskan pada diagram activity berikut.

\subsubsection{Login}

Aplikasi mempunyai beberapa pengguna yaitu security dan karyawan. Oleh karena itu, pembagian kedua hak akses tersebut dipisahkan pada saat login. Alur kerja proses ini dapat dilihat pada Gambar 3.

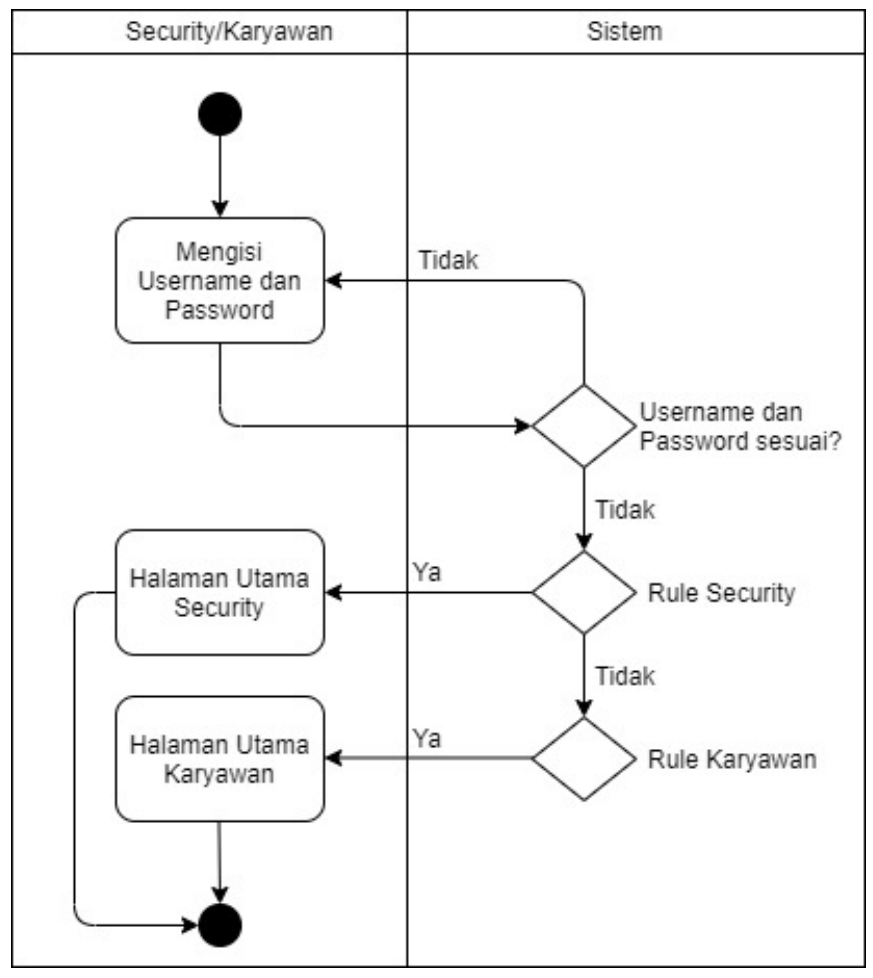

Gambar 3. Activity Diagram Login

Gambar 3 menggambarkan proses aktivitas login oleh security atau karyawan. Gambar tersebut menjelaskan bahwa security atau pegawai yang ingin login akan divalidasi username dan passwordnya kemudian terdapat pembagian hak akses sesuai dengan bagian masing-masing. Hak akses security, akan dapat mencatat informasi tamu yang berkunjung, melihat history dan detail informasi tamu. Sedangkan hak akses karyawan yaitu membuat visitor appointment dan melihat detail informasi tamu.

\subsubsection{Proses Penerimaan Tamu}

Penerimaan tamu diawali dari karyawan yang membuat visitor appointment sebelum tamu datang ke perusahaan, lalu kemudian setelah tamu datang, maka tamu akan melapor ke pihak security yang kemudian akan mencatat seluruh data tamu yang berkunjung mulai dari informasi kunjungan, konfirmasi dari pegawai berupa list tamu, waktu mulai kunjungan hingga waku selesai kunjungan.

Dalam pencatatan data tamu terdapat data yang dikirim antara dua aktor dengan media notifikasi. Penjelasan lebih lanjut dapat dilihat pada Gambar 4. 


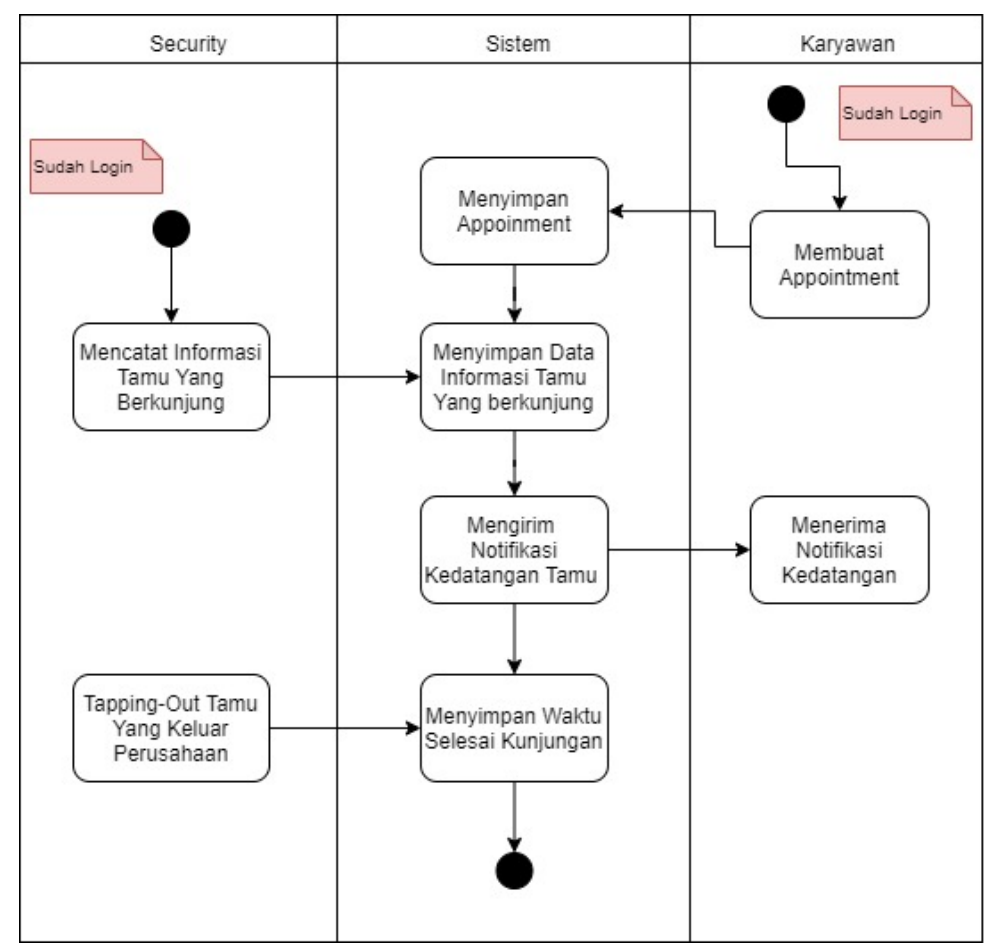

Gambar 4. Activity Diagram Mencatat Data Tamu

\subsubsection{Melihat Data History Dan Detail Tamu yang Berkunjung}

Hasil pencatatan data tamu tersebut dapat dilihat pada menu melihat data detail tamu yang berkunjung. Alur melihat data detail tamu yang berkunjung dapat dilihat pada Gambar 5.

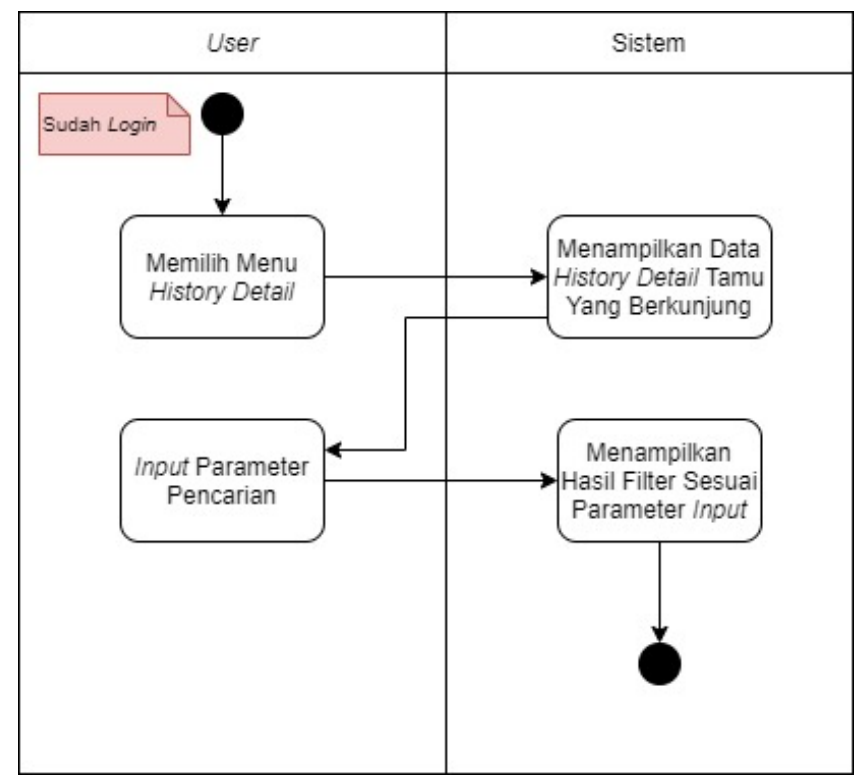

Gambar 5. Melihat Data Detail Tamu yang Berkunjung

Gambar 5 menggambarkan proses aktivitas melihat data detail tamu yang berkunjung. User juga dapat melakukan pencarian dengan mengisi parameter pada textbox yang disediakan. Kemudian sistem akan menampilkan hasil pencarian tersebut. Filter parameter pencarian diantaranya yaitu nama tamu, tanggal tamu berkunjung serta nama pegawai yang ditemui. 


\subsection{Analisa Perancangan Basis Data}

Perancangan basis data (database) memiliki beberapa tujuan diantaranya untuk memenuhi kebutuhan akan informasi dari pengguna dan aplikasi yang digunakan serta menyediakan struktur informasi yang natural dan mudah di mengerti oleh pengguna sehingga akan lebih tertata rapih dalam suatu pembuatan basis data. Di samping itu perancangan basis data dimaksudkan untuk mendukung kebutuhan pemrosesan dan beberapa obyek kinerja dari suatu sistem database dan beberapa obyek penampilan (response time, processing time, dan storage space).

Dalam perancangan ini akan dijabarkan tabel-tabel yang akan digunakan dalam pengembangan sistem. Tabel-tabel tersebut yang nantinya akan dijadikan sebagai tempat penampungan data dalam setiap interaksi pada Visitor Management System (VMS) PT. Epson Batam. Spesifikasi database yang digunakan penulis adalah Microsoft SQL Server 2012.

Rancangan Tabel pada basis data Visitor Management System PT Epson Batam ditunjukkan pada Tabel 1 .

Tabel 1. Rancangan Tabel VMS PT. Epson Batam

\begin{tabular}{|c|c|c|c|c|}
\hline No & Tabel & Keterangan Tabel & $\begin{array}{l}\text { Jml } \\
\text { Field }\end{array}$ & $\begin{array}{l}\text { Primary } \\
\text { Key }\end{array}$ \\
\hline 1 & [Security_mtBuilding] & $\begin{array}{l}\text { Merupakan tabel master building. } \\
\text { Menyimpan beberapa lokasi gedung } \\
\text { yang ada di PT Epson Batam. }\end{array}$ & 2 & buildingID \\
\hline 2 & [Security_mtIdentity] & $\begin{array}{l}\text { Merupakan tabel master identitas } \\
\text { tamu berupa KTP, SIM atau yang } \\
\text { lainnya. }\end{array}$ & 2 & identityID \\
\hline 3 & [Security_dtVisitor] & $\begin{array}{l}\text { Merupakan tabel transaksi yang akan } \\
\text { menyimpan data kedatangan visitor } \\
\text { saat diinput oleh security PEB. }\end{array}$ & 11 & whouseID \\
\hline 4 & [lobby_dtVisitor] & $\begin{array}{l}\text { Marupakan tabel transaksi yang akan } \\
\text { menyimpan data visitor saat } \\
\text { karyawan PEB membuat } \\
\text { appointment. }\end{array}$ & 10 & projID \\
\hline 5 & [MtEmployee] & $\begin{array}{l}\text { Merupakan tabel master yang berisi } \\
\text { informasi detail data karyawan. }\end{array}$ & 23 & Employee No \\
\hline 6 & [MtDivision] & $\begin{array}{l}\text { Merupakan tabel master yang berisi } \\
\text { data divisi di PT. Epson Batam. }\end{array}$ & 8 & DivisiID \\
\hline 7 & [MtDept] & $\begin{array}{l}\text { Merupakan tabel master yang berisi } \\
\text { data departemen di PT. Epson Batam. }\end{array}$ & 9 & DeptID \\
\hline 8 & [MtUser] & $\begin{array}{l}\text { Merupakan tabel master user yang } \\
\text { berisi data user login yang terkoneksi } \\
\text { dengan data karyawan. }\end{array}$ & 18 & UserID \\
\hline 9 & [Dt_AppUser] & $\begin{array}{l}\text { Merupakan tabel transaksi } \\
\text { yang berisi data user akses. }\end{array}$ & 2 & - \\
\hline
\end{tabular}

\subsection{Analisa Perancangan Antarmuka}

Perancangan antarmuka (user interface) sebagai mekanisme komunikasi antara pengguna (user) dengan sistem bertujuan untuk membuat tampilan sistem yang efisien yang dapat memberikan arus balik yang tepat kepada pengguna dan memberikan kemudahan dalam memakai atau menjalankan sistem agar lebih interaktif dan komunikatif. 


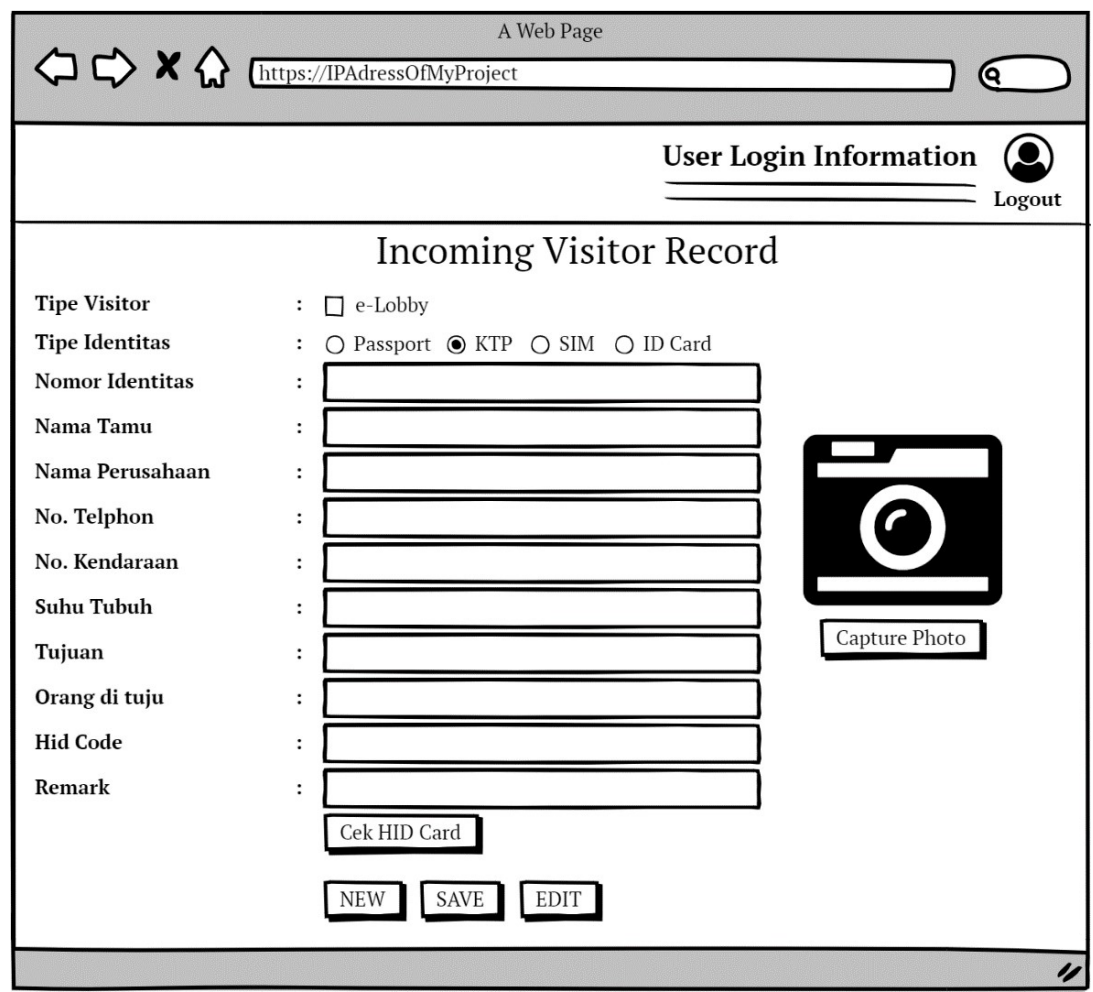

Gambar 6. Rancangan Halaman: Incoming Visitor Record

Pada halaman ini security akan mencatat informasi dan data yang dibutuhkan, seperti nomor indentitas, nama tamu, nama perusahaan, nomor telepon, nomor kendaraan, suhu tubuh, tujuan dan informasi lain yang dibutuhkan.

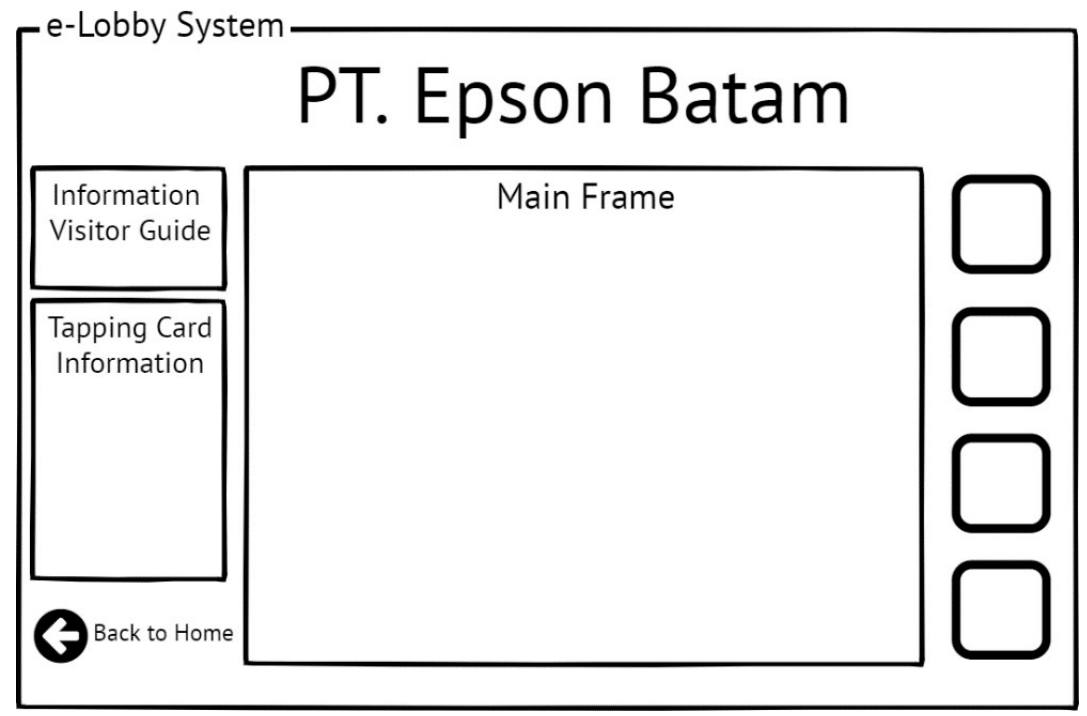

Gambar 7. Perancangan Halaman: Tapping eLobby

Halaman ini merupakan tampilan ketika tamu sudah menyelesaikan kunjungannya dan ingin keluar meninggalkan lokasi perusahaan. Di pos security, tamu akan melakukan tapping out dan mengembalikan kartu HID Card kepada security. Aplikasi akan otomatis me-record waktu keluar tamu, dan meng-update status kunjungan menjadi "finish". 


\section{Implementasi}

Implementasi antarmuka terdiri atas halaman incoming visitor record dan tapping view.

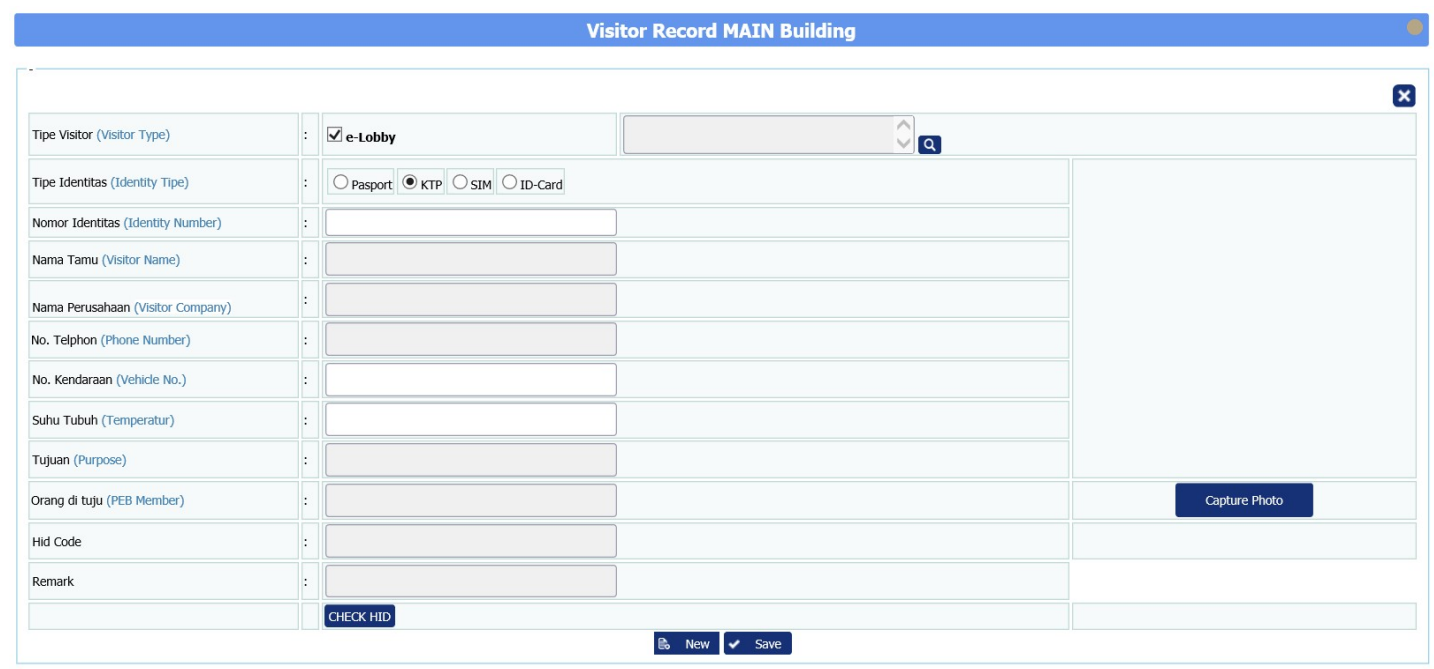

Gambar 8. Tampilan Halaman: Incoming Visitor Record

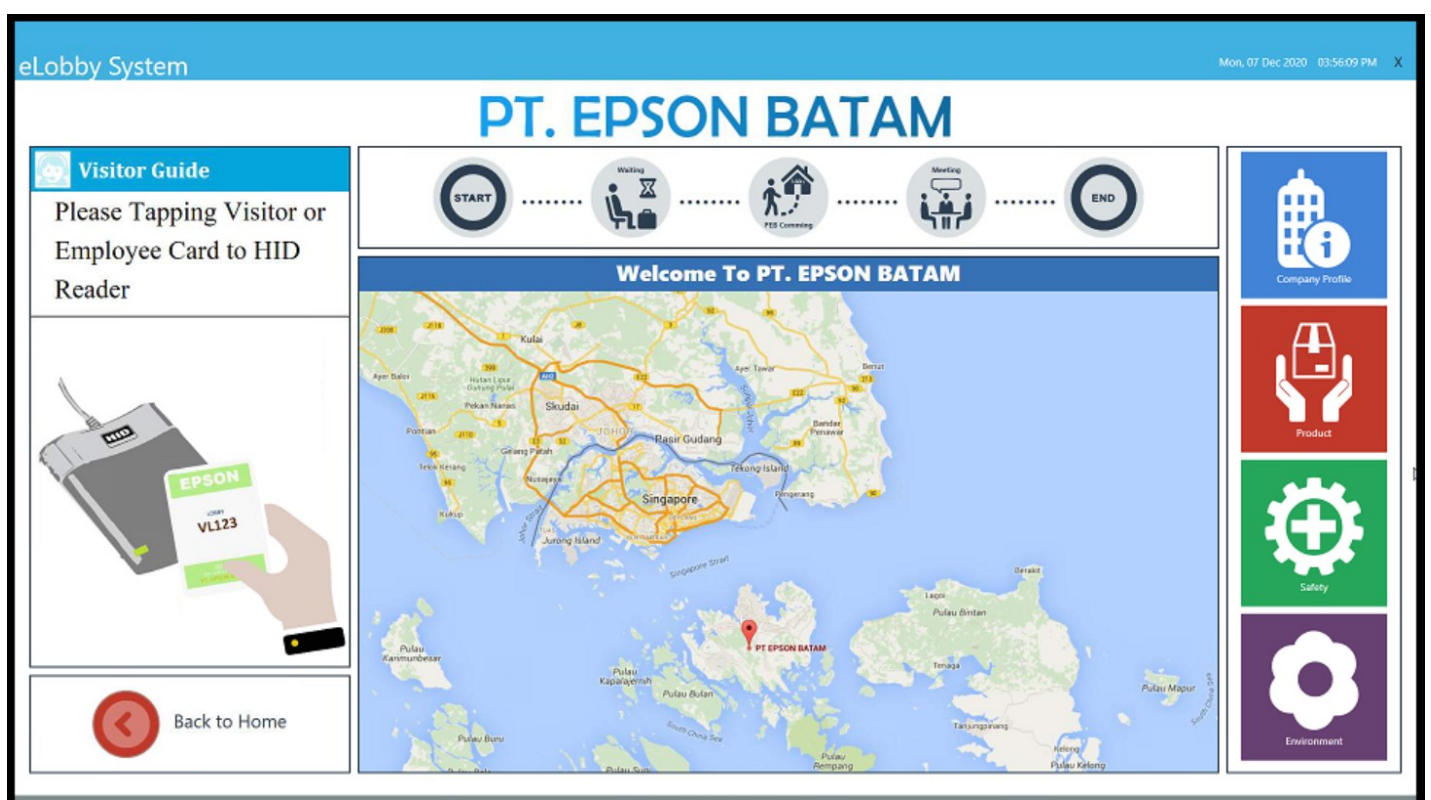

Gambar 9. Tampilan Halaman: e-Lobby

\section{Pengujian aplikasi}

Tahap pengujian sistem dilakukan untuk memastikan setiap fungsi pada aplikasi berjalan dengan baik, maka pengujian sistem pada penelitian ini menggunakan black box testing. Pengujian black box digunakan untuk menguji fungsi-fungsi khusus dari perangkat lunak yang dirancang.

Teknik pengujian black box merupakan suatu pengujian yang dilakukan untuk mengamati hasil dari eksekusi pada aplikasi penulis bangun. Pengamatan hasil ini melalui data uji dan memeriksa fungsional dari perangkat lunak itu sendiri. 


\section{Kesimpulan}

Sistem informasi eLobbi Management yang dibangunkan dapat diterima di lingkungan perusahaan PT. Epson Batam. Sistem informasi e-Lobby memiliki beberapa proses seperti pencatatan tamu pada pos penjagaan serta menyediakan menu janji temu untuk kunjungan yang terkoneksi dengan aplikasi e-lobby. Sistem dilengkapi notifikasi otomatis melalui pesanan ringkas (SMS) kepada karyawan ketika tamu sudah tiba di ruangan lobi perusahaan. Sistem menyediakan menu untuk penelusuran pengunjung jika sekiranya ada keperluan untuk melacak siapa saja tamu yang berkunjung ke PT. Epson Batam pada waktu tertentu.

Ada beberapa hal yang perlu diperbaiki pada pengembangan ke depan antara lain mengembangkan e-Lobby sehingga dapat diintegrasikan dengan alat pengukur suhu sehingga pengunjung bisa meminimalkan kontek dengan orang dan peralatan yang ada di perusahaan PT. Epson Batam.

\section{Daftar Pustaka}

[1] A. Fadjar, "Pentingnya Kualitas Kemampuan Petugas Front Desk Agent Di Hotel Sahid Jaya Solo." Tourism, Hospitality and Culinary Journal, vol. 1, no. 1, pp. 1, 2016.

[2] HRD, Company Profile PT. Epson Batam. Human Resource Department PT. Epson Batam, 2016.

[3] I. G. Wursanto, Dasar-dasar Ilmu Organisasi. Yogyakarta: Andi, 2005.

[4] R. H. Soemarto and D. Lukas, Sekretaris Profesional. Yogyakarta: Kanisius, 2000.

[5] A. Nugroho, Rekayasa Perangkat Lunak Berbasis Objek dengan Metode USDP. Yogyakarta: Andi offset, 2010.

[6] L. Ahmad, and Munawir, Sistem Informasi Manajemen. Banda Aceh: Penerbit Lembaga Komunitas Informasi Teknologi Aceh (KITA), April 2018.

[7] M. Muslihudin, and Oktafianto, Analisis dan Perancangan Sistem Informasi Menggunakan Model Terstruktur dan UML. Yogyakarta: ANDI offset, 2016.

[8] Nafiudin, Sistem Informasi Manajemen. Pasuruan: Qiara Media, 2019.

[9] Kertahadi, Sistem Informasi Manajemen. Jakarta: PT. Pustaka Binaman Pressindo, 2007.

[10] G. Murdick, Roger/Joel E. Ross/James R. Claggett, Sistem Informasi Untuk Manajemen Modern. Jakarta: Erlangga, 1993.

[11] Hendri, Sistem Informasi Pencatatan Gangguan Jaringan Berbasis Web. Jakarta: Universitas Bina Sarana Informatika Jakarta, 2017.

[12] Sedianingsih. Teori dan Praktik Administrasi Kesekretariatan. Jakarta: Kencana Predana Media Group, 2010.

[13] S. Mulyani, Sistem Informasi manajemen Rumah Sakit: Analisis dan Perancangan. Bandung: ABSI Sistematika, Mei 2016.

[14] A. Fatoni, Normalisa and A. F. Zulfikar, "Merancang Sistem Aplikasi Pendaftaran Kartu Kredit di Bank Panin Kantor Kas Permata Taman Palem," Journal of Engineering, Technology, and Applied Science, vol. 2, no. 1, pp. 59-85, 2020. doi: https://doi.org/10.36079/lamintang.jetas0201.95

[15] N. H. Hasbullah and N. A. Z. Mohd Noor, "Sistem Temujanji Interaktif Berasaskan WEB", Journal of Engineering, Technology and Applied Science, vol. 2, no. 3, pp. 110-117, Dec. 2020. doi: https://doi.org/10.36079/lamintang.jetas-0203.144

[16] A. Fatoni, Normalisa, and A. F. Zulfikar, "Merancang Sistem Aplikasi Pendaftaran Kartu Kredit di Bank Panin Kantor Kas Permata Taman Palem", Journal of Engineering, Technology and Applied Science, vol. 2, no. 1, pp. 59-85, Apr. 2020. doi: https://doi.org/10.36079/lamintang.jetas-0201.95

[17] F. D. Putra, J. Riyanto, and A. F. Zulfikar, "Rancang Bangun Sistem Informasi Manajemen Aset pada Universitas Pamulang Berbasis WEB," Journal of Engineering, Technology, and Applied Science, vol. 2, no.1 pp. 32-50, 2020. doi: https://doi.org/10.36079/lamintang.jetas0201.93

[18] Yulianti and Normalisa, "Implementasi Arsitektur Client-Server dan Model-View-Controller untuk Membangun Aplikasi Administrasi di SMK Averus Jakarta," Journal of Engineering, Technology, and Applied Science, vol. 2, no. 1, pp. 1-18, 2020. doi: https://doi.org/10.36079/lamintang.jetas-0201.91

[19] D. Putra, J. Riyanto, and A. F. Zulfikar, "Rancang Bangun Sistem Informasi Manajemen Aset pada Universitas Pamulang Berbasis WEB", Journal of Engineering, Technology and Applied 
Science, vol. 2, no. 1, pp. 32-50, Apr. 2020. doi: https://doi.org/10.36079/lamintang.jetas0201.93

[20] N. F. Z. Zakaria, Z. Zainal Abidin, M. A. Abdullah Zawawi, and S. N. Shuhada, "Bloodbuddy: a Tracking System for Blood Donor Using GPS", Journal of Engineering, Technology and Applied Science, vol. 2, no. 2, pp. 86-102, Aug. 2020. doi: https://doi.org/10.36079/lamintang.jetas-0202.117

[21] S. Apandi, O. Veza, S. Majid, and P. Pratiwi, "Penentuan Bonus Karyawan dengan Menggunakan Metode Analytic Network Process di PT. Global Harvest Precision Engineering", Journal of Engineering, Technology and Applied Science, vol. 2, no. 1, pp. 5158, Apr. 2020. doi: https://doi.org/10.36079/lamintang.jetas-0201.94

[22] A. Suganda, I. Y. Panessai, R. D. Permatasari, and Pratiwi, "Sistem Informasi Pemantauan Retribusi Pada Menara Telekomunikasi", International Journal of Education, Science, Technology, and Engineering, vol. 2, no. 2, pp. 97-111, 2019. doi: https://doi.org/10.36079/lamintang.ijeste-0202.27

[23] M. Olva, R. D. Permatasari, S. Majid, P. Syair, and A. Suganda, "Pemanfaatan Dasbor pada Pemantauan Data Transaksi Penjualan", Journal of Engineering, Technology and Applied Science, vol. 3, no. 1, pp. 1-15, Apr. 2021.

[24] L. Swastina and A. S. Riadi, "Implementation of Feeder System to Support Monitoring the Potential Malnutrition", International Journal of Education, Science, Technology, and Engineering, vol. 3, no. 2, pp. 48-59, Dec. 2020. doi: https://doi.org/10.36079/lamintang.ijeste0302.114

[25] Yudhanti and D. Admella, Management System Konservasi Hutan Tanaman Mangrove. Indonesia: Universitas Tanjungpura, 2019.

[26] Sitorus and Lamhot, Algoritma Dan Pemrograman. Yogyakarta: ANDI, 2015.

[27] Raharjo and Andre. “Apa Itu UML?", January 2018. [Online]. Available: https://bit.ly/2BJuLGh. [Accessed: March, 2021].

[28] A. Lubis, Basis Data Dasar Untuk Mahasiswa Ilmu Komputer. Yogyakarta: Deepublish, Maret 2016.

[29] Pendit and P. Laxman, Makna Informasi: Lanjutan dari Sebuah Perdebatan," dalam Kepustakawanan Indonesia: Potensi dan Tantangannya. Jakarta: Kesaint-Blanc, 1992.

[30] S. Chamidi, "Kaitan antara Data dan Informasi Pendidikan dengan Perencanaan Pendidikan," Jurnal Pendidikan dan Kebudayaan, vol. 48, no, 10, pp. 311-328, 2004.

[31] A. Z. Hasibuan, Metodologi Penelitian pada Bidang Ilmu Komputer dan Teknologi Informasi. Depok, 2007. 